\title{
Derivation of sperm from xenografted testis cells and tissues of the peccary (Tayassu tajacu)
}

\author{
Paulo Henrique Almeida Campos-Junior ${ }^{1}$, Guilherme Mattos Jardim Costa ${ }^{1}$, \\ Gleide Fernandes Avelar ${ }^{1}$, Samyra Maria Santos Nassif Lacerda ${ }^{1}$, Nathália Nogueira da Costa ${ }^{3}$, \\ Otávio Mitio Ohashi ${ }^{3}$, Moysés dos Santos Miranda ${ }^{3}$, Lucíola Silva Barcelos ${ }^{2}$, Érika Cristina Jorge ${ }^{1}$, \\ Diva Anelie Guimarães ${ }^{3}$ and Luiz Renato de França ${ }^{1}$
}

Departments of ${ }^{1}$ Morphology and ${ }^{2}$ Physiology and Biophysics, Federal University of Minas Gerais, Belo Horizonte,

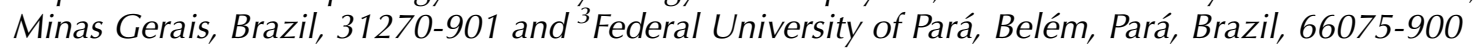

Correspondence should be addressed to L R de França; Email: Irfranca@icb.ufmg.br

\begin{abstract}
Because the collared peccary (Tayassu tajacu) has a peculiar Leydig cell cytoarchitecture, this species represents a unique mammalian model for investigating testis function. Taking advantage of the well-established and very useful testis xenograft technique, in the present study, testis tissue and testis cell suspensions from immature collared peccaries $(n=4 ; 3$ months old) were xenografted in SCID mice $(n=48)$ and evaluated at 2, 4, 6, and 8 months after grafting. Complete spermatogenesis was observed at 6 and 8 months after testis tissue xenografting. However, probably due to de novo testis morphogenesis and low androgen secretion, functionally evaluated by the seminal vesicle weight, a delay in spermatogenesis progression was observed in the testis cell suspension xenografts, with the production of fertile sperm only at 8 months after grafting. Importantly, demonstrating that the peculiar testicular cytoarchitecture of the collared peccary is intrinsically programmed, the unique Leydig cell arrangement observed in this species was re-established after de novo testis morphogenesis. The sperm collected from the xenografts resulted in diploid embryos that expressed the paternally imprinted gene $N N A T$ after ICSI. The present study is the first to demonstrate complete spermatogenesis with the production of fertile sperm from testis cell suspension xenografts in a wild mammalian species. Therefore, due to its unique testicular cytoarchitecture, xenograft techniques, particularly testis cell suspensions, may represent a new and very promising approach to evaluate testis morphogenesis and to investigate spermatogonial stem cell physiology and niche in the collared peccary.

Reproduction (2014) 147 291-299
\end{abstract}

\section{Introduction}

Testis tissue xenograft is a powerful approach developed in the last decade (Honaramooz et al. 2002). In this technique, small fragments of testis from different mammalian donor species (Schlatt et al. 2002, 2010, Honaramooz et al. 2004, 2008, Oatley et al. 2004, Snedaker et al. 2004, Rathi et al. 2006, Arregui et al. 2008, Abrishami et al. 2010, Ehmcke et al. 2011, Abbasi \& Honaramooz 2012), are placed subcutaneously under the back skin of an immunodeficient mouse, where they respond to the rodent gonadotropins, initiating and leading to complete spermatogenesis (Honaramooz et al. 2002, Rodriguez-Sosa \& Dobrinski 2009). As expected, this approach became an attractive strategy to recapitulate and study testis development in non-rodent species and, among several other important applications, could be used to preserve the germplasm of young individuals in which sperm collection is not an option
(Rodriguez-Sosa \& Dobrinski 2009). As a very important aspect, the graft-derived sperm fertility was confirmed using ICSI (Honaramooz et al. 2002, 2004, 2008), leading to the birth of healthy offspring (Ruddock et al. 2003, Nakai et al. 2010).

In another powerful approach, when dissociated testis cells were placed subcutaneously under the back skin of an immunodeficient mouse, the cells were able to organize and rearrange into seminiferous cords (de novo testis morphogenesis), which subsequently developed completely, including the production of viable sperm (Gassei et al. 2006, Honaramooz et al. 2007, Kita et al. 2007). Although it has been used for few donor species (Gassei et al. 2006, Honaramooz et al. 2007, Kita et al. 2007), this fascinating methodology became very important for studies involving cell interactions during testis morphogenesis and could be applied, for instance, to preserve the genome of valuable animals and endangered species. 
Peccaries are suiforms that are found in the American continent, and among the three recognized species belonging to the Tayassuidae family, the collared peccary (Tayassu tajacu) is the most widely spread (Groves \& Grubb 1993). Due to the high quality of its flesh and leather, this species is raised in captivity and is also one of the most hunted in neotropical forests (Robinson \& Redford 1991, Peres 1996).

In recent studies carried out in our laboratory, we demonstrated that the collared peccary presents a unique testicular cytoarchitecture, in which Leydig cells are observed almost exclusively surrounding the seminiferous tubule lobes (Costa et al. 2010, CamposJunior et al. 2012). Taking advantage of this peculiar feature, we found that, different from what is suggested in the literature (de Rooij \& Griswold 2012), Leydig cells probably play a pro-differentiation role in spermatogonial stem cells (Campos-Junior et al. 2012). Therefore, the collared peccary may represent an excellent model for investigating the spermatogonial stem cell physiology and niche as well as for studies involving testis function, hormonal regulation of spermatogenesis and germ cell development. The aim of the present study was to use testis tissue and testis cell suspension xenografts from immature collared peccaries to morphofunctionally evaluate spermatogenesis progression and testis morphogenesis.

\section{Materials and methods}

In the present study, eight collared peccaries (four males and four females) and 48 SCID mice were used, following approved guidelines for the ethical treatment of animals (Ethics Committee on Animal Experimentation - Federal University of Minas Gerais, CETEA - UFMG, protocol number 209/2013).

\section{Donor testis}

Four immature $(\sim 3$ months old) collared peccaries ( $T$. tajacu) weighing $\sim 5 \mathrm{~kg}$ were used as testis donors. The animals raised in captivity were obtained from the Federal University of Pará and EMBRAPA/PA, located in the North region of Brazil (Amazon rainforest; $1^{\circ} 279^{\prime} S, 48^{\circ} 299^{\prime} \mathrm{W}$ ). Immediately after orchiectomy (Guimarães et al. 2013), the testes were transferred to the laboratory in ice-cold DMEM (Cat. No. 10-013-CM, GIBCO) containing 2\% antibiotic/antimycotic solution (Sigma) and supplemented with $10 \%$ of fetal bovine serum (FBS; GIBCO).

\section{Testis tissue xenograft}

Under laboratory conditions, the collected peccary testes were washed three times with DMEM, the tunica albuginea was removed and the testicular parenchyma was then divided into small fragments $\left(\sim 3 \mathrm{~mm}^{3}\right)$ and maintained in supplemented DMEM on ice until xenografting. To evaluate the donor testis histological status, before grafting, representative testis tissue fragments were fixed in Bouin's solution and routinely prepared for histological analysis. Male immunodeficient SCID mice (6-8 weeks old; $n=24)$ were anesthetized (xylazine $(7.9 \mathrm{mg} / \mathrm{kg}) / \mathrm{ketamine}(69.8 \mathrm{mg} / \mathrm{kg})$; Campos-Junior et al. (2011)) and castrated, and during the same procedure, four fragments of donor testis tissue were grafted into a small subcutaneous pocket under the back skin of the recipient mice. Two incisions were made on each side of the dorsal midline, just above the forelimbs and hindlimbs, and they were closed using wound clips (Michel Clips 7.5 mm, Miltex, York, PA, USA).

\section{Testis cell suspension xenograft}

A cell suspension of testis cells was prepared by a two-step enzymatic digestion as described previously (Honaramooz et al. 2002, 2007, Arregui et al. 2008). Subsequently, aliquots of $2.5 \times 10^{6}$ cells in DMEM were prepared and centrifuged at $1000 \mathrm{~g}$ for $5 \mathrm{~min}$, and the pellets were maintained on ice until grafting. The surgical procedure was the same as that described previously for testis tissue xenograft, using, however, different male SCID mice of a similar age (6-8 weeks old; $n=24)$ as recipients.

To evaluate the cell content and viability of the testis cell suspension before xenografting, specific immunolabeling for Sertoli and germ cells and Annexin V/propidium iodide (PI) apoptotic assay were carried out, in a flow cytometer, using four pellets from each donor. For immunolabeling, the cell samples were permeabilized with PBS with $1 \%$ of Tween 20 (Sigma) for $15 \mathrm{~min}$. Non-specific binding was blocked with PBS with $1 \%$ of BSA (Sigma) for 30 min. Primary antibodies against VASA (DDX4, specific germ cell marker; Abcam, Ab13840; 1:200, Cambridge, Cambridgeshire, England.) and GATA4 (specific Sertoli cell marker; Santa Cruz Biotechnology, SC-1237; 1:200) were applied, and the cell suspensions were incubated for $60 \mathrm{~min}$ and antigens were detected by incubation with Alexa Fluor secondary antibodies (488 anti-rabbit (1:500) or 546 anti-goat (1:500)) for $60 \mathrm{~min}$. All previously described steps were carried out at room temperature.

The Annexin V/PI assay was carried out using the ApopNexinAnnexin V FITC Apoptosis Kit (Millipore APT750, Billerica, Massachusets, USA.) following the manufacturer's instructions. The stained cells were acquired and analyzed using FACScan (Becton \& Dickinson, San Jose, California, USA.) and the CellQuest software.

\section{Biometrical and histological evaluations}

Body and graft weights were assessed in mice that received both tissue and cell suspension xenografts at 2, 4, 6, and 8 months after grafting. As an indicator of the presence of bioactive testosterone (Arregui et al. 2008) originating from the collared peccary testis xenograft, seminal vesicle weights were also recorded in mice that received the grafts at the same time points investigated $(2,4,6$, and 8 months). In the control (non-grafted mice), castrated $(n=4)$ and intact $(n=4)$ SCID mice, seminal vesicle weights were recorded only 8 months after grafting.

The grafts were fixed overnight in Bouin's solution, routinely processed, embedded in paraplast, and sectioned $(5 \mu \mathrm{m})$ for 
light microscopy histological evaluation, after staining with hematoxylin and eosin. To investigate the progression of spermatogenesis, the most advanced germ cell type present per seminiferous tubule cross section (150 per animal) was scored in the following five categories: i) Sertoli cell only; ii) gonocytes/spermatogonia; iii) spermatocytes; iv) round or elongated spermatids; and v) mature spermatids/sperm. These data are expressed in percentage. Furthermore, $3 \beta \mathrm{HSD}$ (SC-30820; Santa Cruz Biotechnology) immunofluorescence was also carried out as described previously (Campos-Junior et al. 2012).

\section{Blood perfusion analysis}

Blood perfusion analysis in the xenografted skin was carried out in a non-invasive way and without the use of tracer dyes in anesthetized mice using a laser Doppler perfusion image (LDPI) device (MoorLDPI-2, Moor Instruments, Axminster, Devon, UK). To direct the light beam (830 nm laser) and to avoid interference from surrounding cutaneous blood flow in the measurements, a dark plastic ring was positioned around the xenografts. Nongrafted skin was used as basal control. During the capture of images, the ambient light level was kept at a minimum to avoid any influence on the laser light and the recorded signals. To control for temperature variability, animals were kept at a constant temperature of $37^{\circ} \mathrm{C}$ for $5 \mathrm{~min}$ before and during the measurements. The mean pixel value of each scanned image was calculated using the software MoorLDI V5.3, and the calculated mean flux is expressed as perfusion units (PU), representing the average blood flow in the region of interest.

\section{Sperm recovery from the xenografts}

To evaluate their fertility, sperm cells were recovered from both tissue $(n=3)$ and cell suspension $(n=3)$ xenografts at 8 months after grafting. For this purpose (Nakai et al. 2010), the grafts were minced and dispersed in supplemented DMEM. The obtained tissue suspension was centrifuged for $10 \mathrm{~min}$ at $600 \mathrm{~g}$, and the supernatant was discarded. The sperm cell pellets, mostly sperm, were resuspended in DMEM and maintained at room temperature.

\section{Oocyte sampling and in vitro maturation and ICSI}

Using standard procedures, ovaries from sexually mature female collared peccaries $(n=4)$ were obtained by ovariectomy (Guimarães et al. 2013). Thirty-two cumulus-oocyte complexes (COCs) were collected from follicles in TCM 199 (Sigma) supplemented with 10\% FBS (Gibco, Life Technologies), 20 mM HEPES (Dojindo Laboratories, Kumamoto, Japan), $100 \mathrm{IU} / \mathrm{ml}$ penicillin $\mathrm{G}$ potassium (Sigma), and $0.1 \mathrm{mg} / \mathrm{ml}$ streptomycin sulfate (Sigma). Briefly, about 20 COCs were cultured in $100 \mu \mathrm{l}$ of maturation medium for $48 \mathrm{~h}$ in TCM. After culture, cumulus cells were removed from the oocytes by treatment with $150 \mathrm{IU} / \mathrm{ml}$ hyaluronidase (Sigma) and gentle pipetting. Denuded oocytes with the first polar body were harvested under a
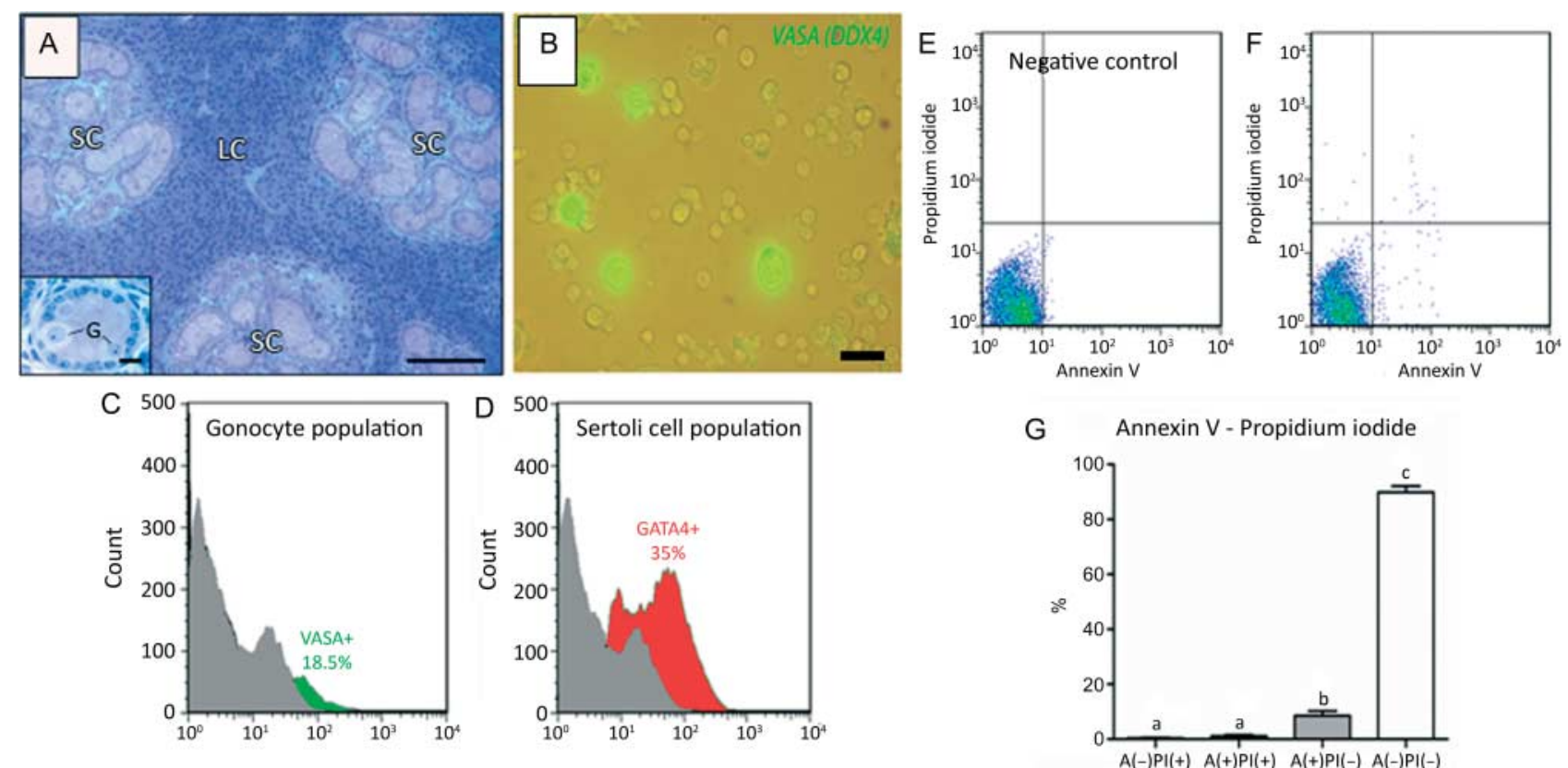

Figure 1 Histological and cell suspension evaluations of immature collared peccary testis parenchyma before xenografting. (A) At 3 months of age, the donor testis parenchyma exhibited the peculiar Leydig cell (LC) cytoarchitecture already described for sexually mature peccaries. In the seminiferous cords (SC), gonocytes (G) were the only germ cell type present at this age and, in the cell suspension, these germ cells (B) were characterized as VASA positive (DDX4 - green). Flow cytometric analysis of the testicular parenchyma cell suspensions revealed that gonocytes (C) and Sertoli cells (D) represented approximately one-sixth $(\sim 19 \%)$ and one-third $(\sim 35 \%)$ respectively of the cell population. In the Annexin $\mathrm{V}$ FITC/PI staining assay $(E, F$, and $G)$, the cell suspension was found to contain mostly viable cells $(\sim 92 \% ; A-/ P I-)$ and few early-phase $(A+/ P I-)$ and late-phase $(\mathrm{A}+/ \mathrm{PI}+)$ apoptotic cells, as well as necrotic cells $(\mathrm{A}-/ \mathrm{PI}+)$. Bar: $\mathrm{A}=200 \mu \mathrm{m}$; inset in $\mathrm{A}=30 \mu \mathrm{m}$ and that in $\mathrm{B}=30 \mu \mathrm{m}$. 
stereomicroscope, and 18 oocytes were considered as in vitro matured.

As the number of obtained viable oocytes was small, ICSI procedure was carried out using spermatozoa only from testis cell suspension xenografts (eight oocytes), and parthenogenetic embryos were also produced as a control (Pereyra-Bonnet et al. 2008). Embryo rate was assessed 24 and $48 \mathrm{~h}$ after ICSI, and the DNA content of the parthenogenetic and ICSI embryos was evaluated using NanoDrop (ND1000, Thermo Scientific). To investigate whether the embryos contained sperm DNA, the expression of the paternally imprinted gene NNAT was also assessed by RT-PCR as follows. Total RNA was isolated from individual embryos using TRIzol Reagent (Life Technologies). Samples were quantified using NanoDrop (ND1000, Thermo
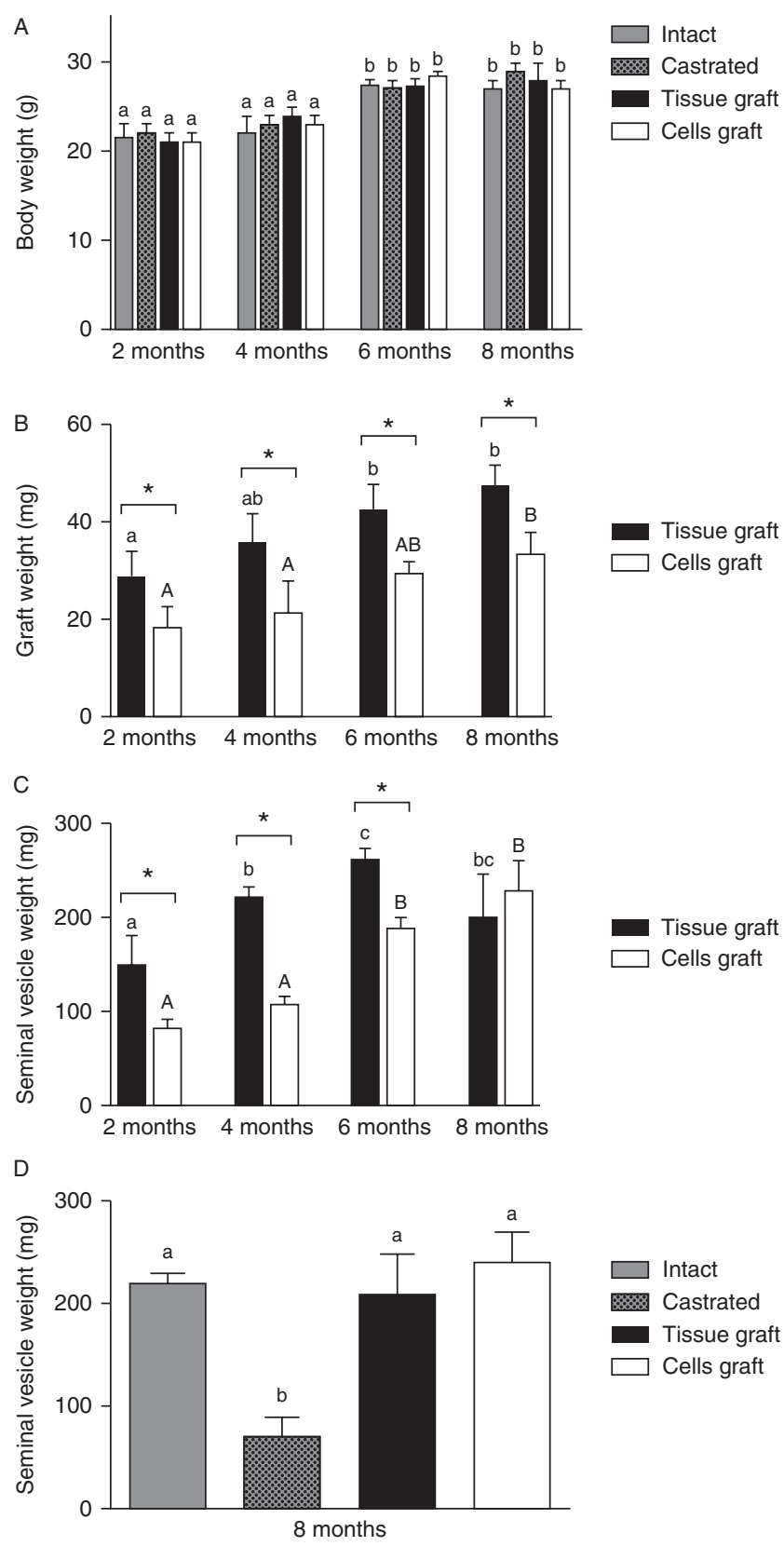

Scientific), and their integrity was examined by gel electrophoresis ( $1 \%$ agarose). Oligo(dT) was used to reverse-transcribe $1 \mathrm{ng}$ of the total RNA into cDNA, following instructions provided with the $\mathrm{RT}^{2}$ Easy First Strand Kit (Qiagen). Oligonucleotides were obtained using the Primer3 software (http:// frodo.wi.mit.edu/) and the mRNA sequences available for swine neuronatin (NNAT, DQ666422) and glyceraldehyde-3-phosphate dehydrogenase (GAPDH, DQ78956) at GenBank (NCBI): NNAT - F: GAGGACCAGCAGTTTAGGA and R: GACTTTAACATCCTGCTTGG; GAPDH - F: AACTTTGGCATTGTGGAAGG and R: ACACATTGGGGGTAGGAACA. PCRs were carried out in a final volume of $25 \mu \mathrm{l}$ using $12.5 \mu \mathrm{l}$ of the Fermentas PCR Master Mix (Thermo Scientific, West Palm Beach, Florida, USA.), $0.4 \mathrm{mM}$ of each primer, and $1 \mu \mathrm{l}$ of the cDNA sample. Amplification was carried out in the Mastercycler (Eppendorf, Hauppauge, New York, USA.), with initial incubation at $94{ }^{\circ} \mathrm{C}$ for $2 \mathrm{~min}$ and $94{ }^{\circ} \mathrm{C}$ for $2 \mathrm{~min}$, followed by 35 cycles of $94{ }^{\circ} \mathrm{C}$ for $15 \mathrm{~s}, 55^{\circ} \mathrm{C}$ for $15 \mathrm{~s}$, and $72{ }^{\circ} \mathrm{C}$ for $1 \mathrm{~min}$. PCR fragments were visualized by gel electrophoresis in $1 \%$ agarose.

\section{Statistical analyses}

All the data were tested for normality and homoscedasticity of the variances. Parametric data were analyzed by ANOVA, and the differences were compared by Tukey's test, whereas Student's t-test was used for two-parameter analysis. All the data are expressed as means \pm s.D., and the significance level considered was $P<0.05$. All the analyses were carried out using the GraphPad Prism (version 5, La Jolla, California, USA). The flow cytometer data were analyzed using the Flowjo software (treeStar Software, Ashland, OR, USA).

\section{Results \\ Collared peccary testis sample evaluations before xenografting}

As has been observed in the testis tissue fragments obtained from 3-month-old peccaries (Fig. 1A), gonocytes were the most advanced germ cell type present in the seminiferous cords and the Sertoli cells were still immature. This figure also clearly shows that the peculiar peccary testis structure observed in sexually

Figure 2 Biometric data obtained at different time points after collared peccary testis tissue and cell suspension xenografting. (A) As can be observed, the body weight of the control (intact and castrated) and recipient (tissue and cell graft) mice were similar at all the time points investigated (2, 4, 6, and 8 months after grafting). (B) Although the grafts exhibited a continuous growth, at all the time points evaluated, the weights of the cell suspension xenografts were lower than those of the tissue xenografts. As can be observed in (C), except at 8 months after grafting, the seminal vesicle weights were consistently higher in mice that received testis tissue xenografts and followed the trend observed for the graft weights. Particularly at 8 months, except in the castrated group, the seminal vesicle weights were similar in the other three groups evaluated (D), and these results indicated that the collared peccary xenografts secreted physiological amounts of bioactive testosterone. Different superscript letters indicate statistical differences $(P<0.05)$. 


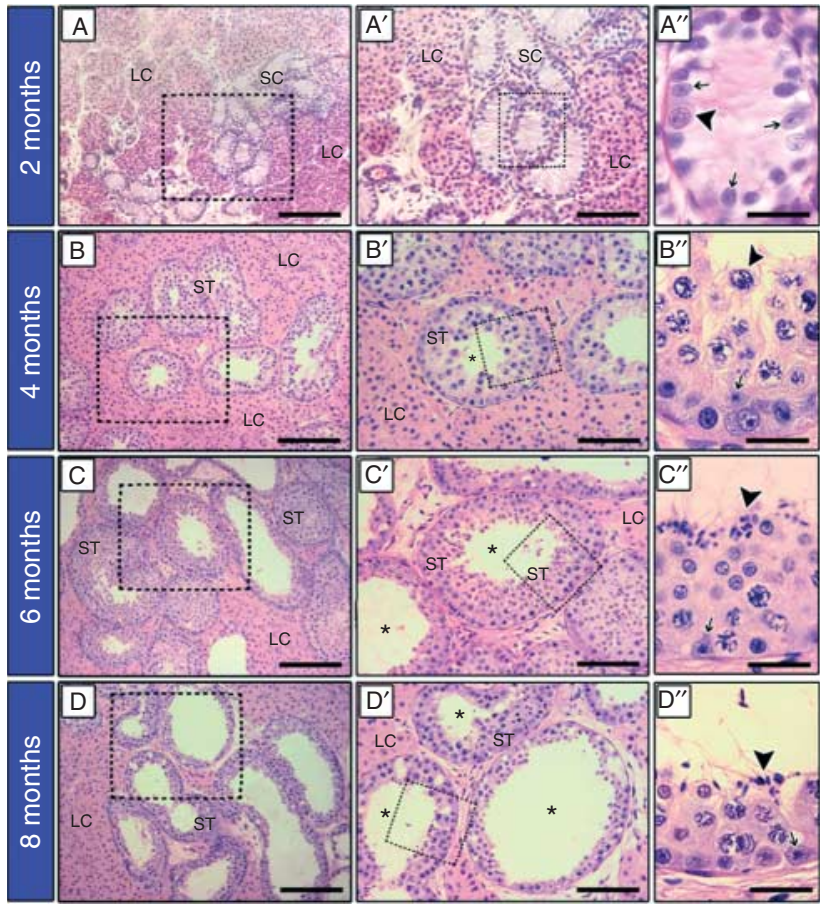

Figure 3 Histological status of collared peccary testis tissue evaluated at different time points after xenografting. As can be observed, overall, the characteristic testicular cytoarchitecture of the collared peccary was maintained and spermatogenesis progressed until the formation of sperm. Therefore, the most advanced germ cell types observed at 2, 4, and 6-8 months were respectively spermatogonia (arrowhead in $A^{\prime \prime}$ ), pachytene spermatocytes (arrowhead in $\mathrm{B}^{\prime \prime}$ ), and mature spermatids/ sperm (arrowheads in $\mathrm{C}^{\prime \prime}$ and $\mathrm{D}^{\prime \prime}$ ). LC, Leydig cells; SC, seminiferous cords; ST, seminiferous tubules; *, tubular lumen; and arrow, Sertoli cell. Bar: A, B, C, and $\mathrm{D}=200 \mu \mathrm{m} ; \mathrm{A}^{\prime}, \mathrm{B}^{\prime}, \mathrm{C}^{\prime}$, and $\mathrm{D}^{\prime}=70 \mu \mathrm{m}$; and $A^{\prime \prime}, B^{\prime \prime}, C^{\prime \prime}$, and $D^{\prime \prime}=40 \mu \mathrm{m}$.

mature animals, where abundant Leydig cells surround the seminiferous tubule lobes (Costa et al. 2010, Campos-Junior et al. 2012), is already established at this early age. The dissociation of the testicular parenchyma indicated that, at 3 months of age, the seminiferous epithelium components represented about $55 \%$ of the testis (gonocytes: $18.5 \% \pm 0.1$; Sertoli cells: $35 \% \pm 5.1$ ) (Fig. 1B, C, and D). Therefore, at this particular age, almost half of the testicular parenchyma comprised interstitial cells, predominantly Leydig cells. Using the Annexin V-FITC/PI staining assay, a high percentage $(92 \% \pm 3.2)$ of viable cells were observed in the testis cell suspensions (Fig. 1E, F, and G).

\section{Biometric data of recipient mice}

Body, graft, and seminal vesicle weights at different time points after testis tissue and cell suspension xenografting are shown in Fig. 2. Although the body weights of mice increased continuously during the experimental period, no significant differences $(P>0.05)$ were observed among the four experimental groups at any time point evaluated (Fig. 2A). It can be observed in this figure that the weights of both graft types increased gradually and that, at all the four time points investigated, the xenografts derived from the testis tissue were bigger $(P<0.05)$ than those derived from the cell suspensions (Fig. 2B). The graft recovery rates obtained in the present study were $100 \%(96 / 96)$ and $78 \%$ (75/96) respectively for the testis tissue and cell suspension xenografts. Except at 8 months, at the other three time points studied the seminal vesicle weights of mice that received testis tissue xenografts were greater $(P<0.05)$ than that observed for the mice grafted with cell suspensions (Fig. 2C and D). However, in contrast to the castrated mice that did not receive grafts, at 8 months after xenografting, the seminal vesicle weights of both the grafted mouse groups reached that of the intact mice $(P>0.05$; Fig. 2D). At the four time points investigated, testis tissue and cell suspension xenograft weights were significantly and positively correlated with the seminal vesicle weights $(r=0.65$ and $r=0.97$ respectively).

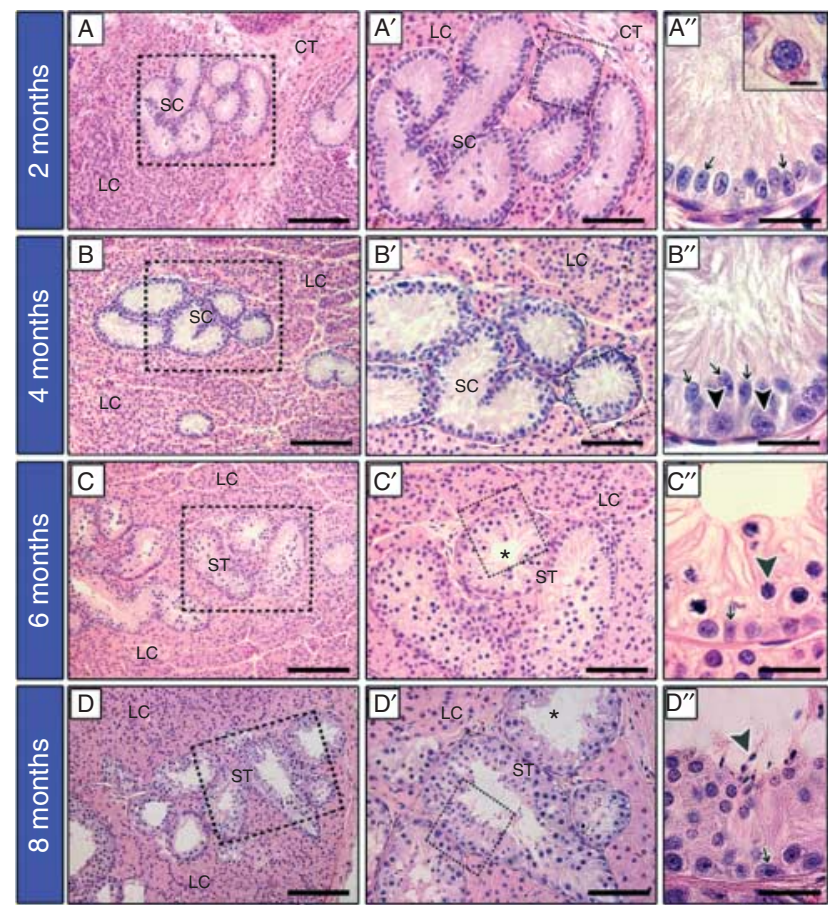

Figure 4 Histological status of collared peccary testis cell suspensions evaluated at different time points after xenografting. As can be observed, after de novo testis morphogenesis, the peculiar testicular cytoarchitecture of the collared peccary was maintained and, although at a slower pace, complete spermatogenesis was observed at 8 months of age. Spermatogonia (inset in $\mathrm{A}^{\prime \prime}$ and arrowhead in $\mathrm{B}^{\prime \prime}$ ), early primary spermatocytes (arrowhead in $C^{\prime \prime}$ ), and mature spermatids/sperm (arrowhead in $\mathrm{D}^{\prime \prime}$ ) were respectively the most advanced germ cell types observed at 2, 4, 6, and 8 months. LC, Leydig cells; SC, seminiferous cords; ST, seminiferous tubules; *, tubular lumen; arrow, Sertoli cell. Bar: $A, B, C$, and $D=200 \mu \mathrm{m} ; A^{\prime}, B^{\prime}, C^{\prime}$, and $D^{\prime}=70 \mu \mathrm{m}$; and $A^{\prime \prime}, B^{\prime \prime}$, $C^{\prime \prime}$, and $D^{\prime \prime}=40 \mu \mathrm{m}$; inset in $A^{\prime \prime}=30 \mu \mathrm{m}$. 


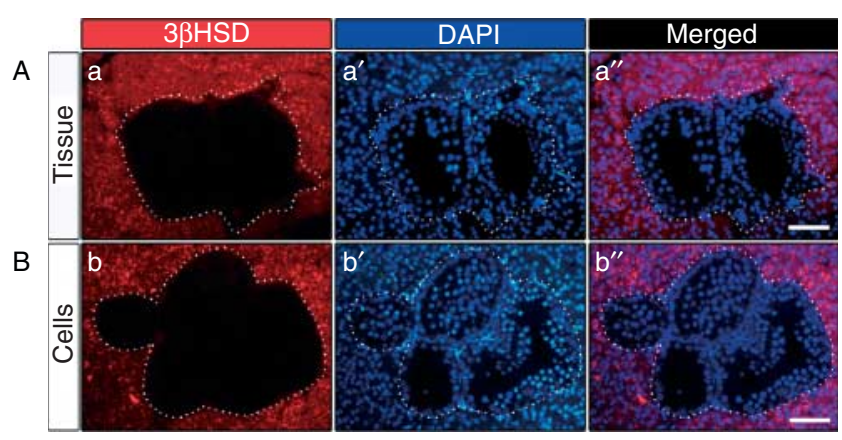

Figure 5 This illustrative figure depicts at 8 months after grafting, using DAPI (in blue) and $3 \beta \mathrm{HSD}$ (Leydig cells cytoplasm in red), that the peculiar collared peccary testis cytoarchitecture were preserved in both testis tissue (A) and cell suspensions (B) xenografts, where Leydig cells were found surrounding the seminiferous tubules lobes. Bar $=70 \mu \mathrm{m}$.

\section{Spermatogenesis progression and de novo testis morphogenesis in the xenografts}

Histological evaluations of both testis tissue and cell suspension xenografts were first carried out at 2 months after grafting. In comparison with the testis histological status observed before grafting (Fig. 1A), the only difference observed was that gonocytes advanced up to spermatogonia. Moreover, testis structure appeared healthy and presented the peculiar characteristic of the collared peccary testis, Sertoli cells were still immature, and no evidence of lumen was observed in the seminiferous cords (Fig. 3A). At 4 months after grafting, the germ cells progressed until the meiotic phase of spermatogenesis and the presence of tubular lumen indicated that the Sertoli cells were more mature
(Fig. 3B). Complete spermatogenesis was established at 6 and 8 months after grafting (Fig. 3C and D) and therefore Sertoli cells presented characteristics of fully mature cells and the tubular lumen was prominent, particularly at 8 months after grafting.

At 2 months after testis cell suspension xenografting, the testis cells interacted and de novo testis morphogenesis had already occurred. As has been observed for the testis tissue grafts, the peculiar collared peccary testis parenchyma cytoarchitecture was re-established, and very few spermatogonia were observed (Fig. 4A). At the other three time points investigated, in comparison with the testis tissue xenografts, spermatogenesis progression was delayed (Fig. 4B and C). Therefore, complete spermatogenesis was observed for the first time only at 8 months after grafting (Fig. 4D). Figure 5 shows, through DAPI and the Leydig cell marker $3 \beta \mathrm{HSD}$, that in both graft approaches used, the unique testicular cytoarchitecture of the collared peccary was preserved.

Although carried out only at 8 months, the quantitative histological evaluations of the xenografts confirmed that spermatogenesis progression was delayed in the cell suspension xenografts. For instance, whereas most of the seminiferous cross sections in the testis tissue grafts presented spermatids, the cell suspension xenograft tubular profiles evaluated presented mainly spermatocytes (Fig. 6A). At the same time point, in comparison with the non-grafted SCID mice, the blood perfusion analysis indicated that the testis tissue and cell suspension xenografts were $\sim 3.5$-fold more vascularized in the grafted mice $(P<0.05$; Fig. 6B and $\mathrm{C})$.
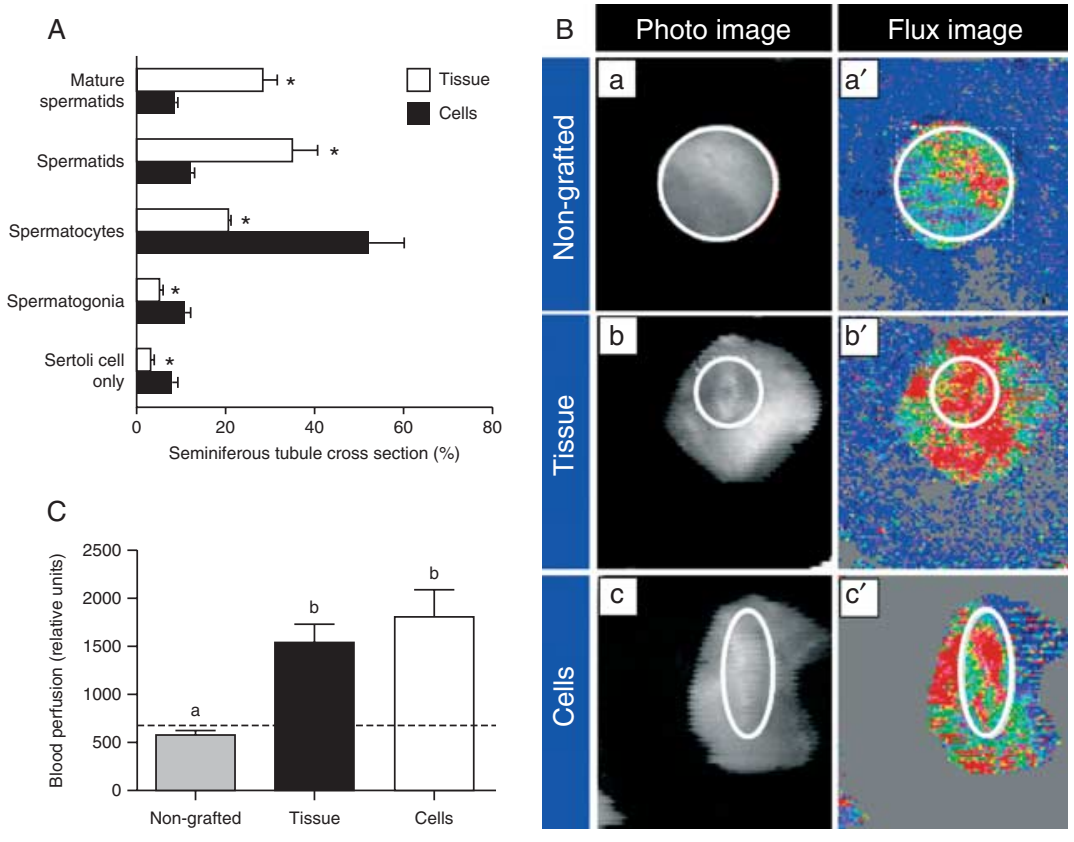

Figure 6 Percentage of seminiferous tubule cross sections depicting different germ cell types and blood perfusion analysis results for both testis tissue and cell suspensions at 8 months after xenografting. (A) Whereas most of the seminiferous tubule cross sections derived from testis tissue grafts contained germ cells in the spermiogenic phase, in the cell suspension grafts the tubular cross sections containing cells in the meiotic phase were the predominant profiles. In both xenograft approaches, few Sertoli cell-only tubular cross sections were observed. Using laser Doppler scanner image analyses (B), it could be observed that, in comparison with the non-grafted SCID mice (a and $\left.a^{\prime}\right)$, in mice grafted with testis tissue (b and $b^{\prime}$ ) and cell suspension xenografts (c and $c^{\prime}$ ) approximately threefold higher blood perfusion was observed (C). Asterisk and different superscript letters indicate statistical differences $(P<0.05)$. 

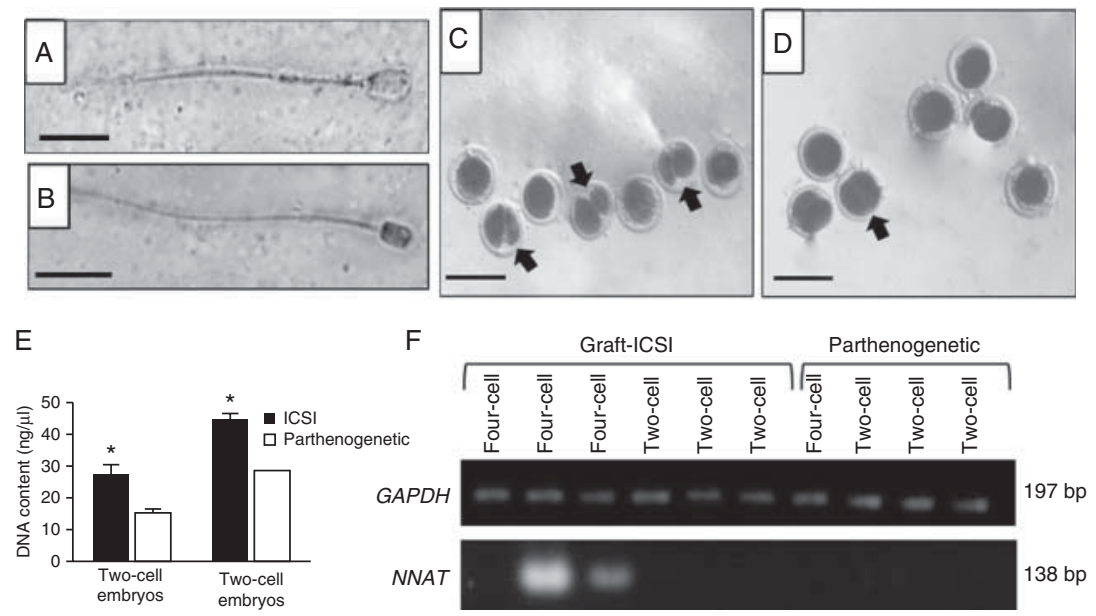

Figure 7 Collared peccary sperm harvest and fertility test. As can be observed, collared peccary sperm were successfully recovered from both testis tissue (A) and cell suspension (B) xenografts. After ICSI, the sperm from the cell suspension grafts were able to produce two-cell (arrows in C) and four-cell (arrow in D) embryos respectively 24 and $72 \mathrm{~h}$ after in vitro culture. The DNA content of sperm injected and the parthenogenetic embryos suggested that these embryos were diploid (E). Reinforcing that these embryos expressed the paternal genome, NNAT (paternally imprinted gene) expression was observed in two-thirds of the embryos, whereas the expression of GAPDH (constitutive gene) was found in all the embryos (F). Bar: $A$ and $B=8 \mu \mathrm{m}$ and $C$ and $\mathrm{D}=600 \mu \mathrm{m}$. The asterisk indicates statistical differences $(P<0.05)$.

\section{Sperm fertility evaluation}

As can be observed in Fig. 7A and B, the collared peccary sperm produced in the xenografts were successfully harvested. These graft-derived sperm, evaluated by ICSI, were able to produce two-cell and four-cell embryos (Table 1 and Fig. 7C and D) and, suggesting that these embryos were diploid, the DNA content of these graft-derived ICSI embryos was approximately twofold higher than that found in the parthenogenetic control embryos (Fig. 7E). Corroborating this finding, the expression of the paternally imprinted gene NNAT was observed exclusively in the four-cell (two of three) ICSI embryos, whereas that of $G A P D H$ (constitutive gene) was observed in the injected and parthenogenetic embryos (Fig. 7F).

\section{Discussion}

Using testis tissue and testis cell suspension xenografts from immature collared peccaries, we observed the occurrence of complete spermatogenesis. Particularly, our data suggest, for the first time in a wild mammalian species, that sperm produced from the testis cell suspension grafts are able to generate diploid embryos expressing NNAT, a paternally imprinted gene. The peculiar testicular cytoarchitecture of the collared peccary (Costa et al. 2010, Campos-Junior et al. 2012) was also re-established when the testis cell suspensions were xenografted in immunodeficient mice. Therefore, among other potential applications, collared peccary testis xenografts can be used to investigate spermatogonial stem cell physiology and niche, as well as mechanisms involved in testis morphogenesis in this species presenting a unique Leydig cell arrangement.

Similar to several other mammalian species (Schlatt et al. 2002, Honaramooz et al. 2004, 2008, Oatley et al. 2004, Snedaker et al. 2004, Rathi et al. 2006,
Arregui et al. 2008, Abrishami et al. 2010, Abbasi \& Honaramooz 2011, Gourdon \& Travis 2011), in the present study, we demonstrated that testis fragments from pre-pubertal collared peccaries were successfully preserved under the back skin of SCID mice, with complete spermatogenesis being observed at 6 months after grafting. Additionally, when testis cells isolated from the same peccaries were xenografted, they were able to interact and de novo testis morphogenesis occurred, with complete spermatogenesis being observed only at 8 months after xenografting. Except for a few other species investigated in this aspect (mice, Kita et al. (2007), domestic pig, Honaramooz et al. (2007), and sheep, Arregui et al. (2008)), to our knowledge, this is the first study to demonstrate the morphogenetic capacity of testis cells in a wild species.

Under captivity conditions, sperm release (puberty) in the seminiferous tubule lumen in the collared peccary is first observed at 11-12 months of age (Guimarães et al. 2013). Therefore, probably due to the more mature hypothalamic-pituitary-gonadal axis in the recipient mice (Rodriguez-Sosa \& Dobrinski 2009), the first spermiation in peccary testis tissue xenograft is clearly advanced (Schlatt et al. 2002, Honaramooz et al. 2004, 2008, Oatley et al. 2004, Rathi et al. 2006, Arregui et al. 2008, Abrishami et al. 2010, Abbasi \& Honaramooz 2011, Gourdon \& Travis 2011). However, because the initial cellular interactions and testis reorganization in peccaries investigated in the present

Table 1 In vitro development of collared peccary oocytes injected with sperm derived from the testis cell suspension xenograft.

\begin{tabular}{lccc}
\hline $\begin{array}{l}\text { Experimental } \\
\text { group }\end{array}$ & $\begin{array}{c}\text { Number of } \\
\text { mature oocytes }\end{array}$ & $\begin{array}{c}\text { Two-cell } \\
\text { embryos }(\%)\end{array}$ & $\begin{array}{c}\text { Four-cell } \\
\text { embryos }(\%)\end{array}$ \\
Graft-ICSI & 8 & $75(6 / 8)$ & $37.5(3 / 8)$ \\
Parthenogenetic & 10 & $40(4 / 10)$ & $10(1 / 10)$ \\
\hline
\end{tabular}


study take $\sim 6$ weeks to occur (PHA Campos-Junior, GM) Costa \& LR França 2013, unpublished data), this advancement was less evident in the testis cell suspension xenografts. Furthermore, the unique testicular cytoarchitecture of the collared peccary was re-established after de novo testis morphogenesis, which strongly suggests that this peculiar feature is intrinsically programmed by the donor cells, and this distinct characteristic provides a new and very useful tool to investigate testis development and function.

In agreement with the literature (Schlatt et al. 2002, Honaramooz et al. 2004, 2008, Oatley et al. 2004, Arregui et al. 2008), the increase in the seminal vesicle weight of recipient mice demonstrated that the collared peccary grafts were responsive to mouse gonadotropins, producing enough bioactive androgens to support complete spermatogenesis. The significant and positive correlation between the seminal vesicle and graft weights, as well as the graft histological status (i.e., Sertoli cell nuclear morphology, lumen formation, and spermatogenesis progression), over the four time points investigated is a good indication of the importance of androgen secretion for graft development and maturation. Therefore, in comparison with the testis tissue xenografts, the delay in spermatogenesis progression observed in the testis cell suspension grafts is a functional consequence of low androgen levels.

Although some studies have shown that sperm produced in testis xenografts are able to produce diploid embryos and healthy progeny (Honaramooz et al. 2004, 2008, Nakai et al. 2010), the fertility of cell suspension graft-derived sperm has never been evaluated in a wild species. In the present study, we were able to successfully collect sperm from collared peccary testis xenografts and, also for the first time, harvest peccary oocytes, which subsequently after standard ICSI procedures (Pereyra-Bonnet et al. 2008) resulted in diploid embryos. Using the PCR technique, we observed that twothirds of the four-cell embryos obtained expressed the paternally imprinted gene NNAT (Park et al. 2011, Chankitisakul et al. 2012). The low ICSI efficiency reported in the present study probably occurred due to the absence of standardized protocols for this species.

In summary, the present study is the first to show complete spermatogenesis with the production of fertile sperm from testis cell suspension xenografts in a wild mammalian species. Importantly, demonstrating that the peculiar testicular cytoarchitecture of the collared peccary is intrinsically programmed, the unique Leydig cell arrangement observed in this species was re-established after de novo testis morphogenesis. Therefore, xenograft techniques, particularly testis cell suspensions, may represent a new and very promising approach to evaluate testis morphogenesis and to investigate spermatogonial stem cell physiology and niche in peccaries, as well as in mammals in general.

\section{Declaration of interest}

The authors declare that there is no conflict of interest that could be perceived as prejudicing the impartiality of the research reported.

\section{Funding}

Support by FAPEMIG, CNPq and FAPESPA.

\section{Acknowledgements}

The authors thank Mara Lívia Santos for providing technical help. They also thank the FAPEMIG and CNPq for awarding scholarships to PHACJ, GMJC, LSB, and SMSNL. LSB additionally thanks INCT-Nanobiofar (CNPq/MCT/FAPEMIG).

\section{References}

Abbasi S \& Honaramooz A 2011 Xenografting of testis tissue from bison calf donors into recipient mice as a strategy for salvaging genetic material. Theriogenology 76 607-614. (doi:10.1016/j.theriogenology. 2011.03.011)

Abbasi S \& Honaramooz A 2012 Feasibility of salvaging genetic potential of post-mortem fawns: production of sperm in testis tissue xenografts from immature donor white-tailed deer (Odocoileus virginianus) in recipient mice. Animal Reproduction Science 135 47-52. (doi:10.1016/ j.anireprosci.2012.09.007)

Abrishami M, Abbasi S \& Honaramooz A 2010 The effect of donor age on progression of spermatogenesis in canine testicular tissue after xenografting into immunodeficient mice. Theriogenology 73 512-522. (doi:10.1016/j.theriogenology.2009.09.035)

Arregui L, Rathi R, Megee SO, Honaramooz A, Gomendio M, Roldan ER \& Dobrinski I 2008 Xenografting of sheep testis tissue and isolated cells as a model for preservation of genetic material from endangered ungulates. Reproduction 136 85-93. (doi:10.1530/REP-07-0433)

Campos-Junior PHA, Silva CA, Grazia JG, Soares MB, Santos RR \& Viana JH 2011 Use of ultrasound biomicroscopy to evaluate induced ovarian follicular growth and ovulation in mice. Laboratory Animals 45 254-258. (doi:10.1258/la.2011.011031)

Campos-Junior PHA, Costa GM, Lacerda SM, Rezende-Neto JV, de Paula AM, Hofmann MC \& França LR 2012 The spermatogonial stem cell niche in the collared peccary (Tayassu tajacu). Biology of Reproduction 86 1-10. (doi:10.1095/biolreprod.111.095430)

Chankitisakul V, Tharasanit T, Phutikanit N, Tasripoo K, Nagai T \& Techakumphu M 2012 Lacking expression of paternally-expressed gene confirms the failure of syngamy after intracytoplasmic sperm injection in swamp buffalo (Bubalus bubalis). Theriogenology 15 1415-1424. (doi:10.1016/j.theriogenology.2011.11.007)

Costa GM, Leal MC, Silva JV, Ferreira AC, Guimarães DA \& França LR 2010 Spermatogenic cycle length and sperm production in a feral pig species (collared peccary, Tayassu tajacu). Journal of Andrology 31 221-230. (doi:10.2164/jandrol.109.008524)

Ehmcke J, Gassei K, Westernströer B \& Schlatt S 2011 Immature rhesus monkey (Macaca mulatta) testis xenografts show increased growth, but not enhanced seminiferous differentiation, under human chorionic gonadotropin treatment of nude mouse recipients. International Journal of Andrology 34 e459-e467. (doi:10.1111/j.1365-2605.2011. 01179.x)

Gassei K, Schlatt S \& Ehmcke J 2006 De novo morphogenesis of seminiferous tubules from dissociated immature rat testicular cells in xenografts. Journal of Andrology 27 611-618. (doi:10.2164/jandrol. 05207)

Gourdon JC \& Travis AJ 2011 Spermatogenesis in ferret testis xenografts: a new model. Comparative Medicine 61 145-149. 
Groves CP \& Grubb P 1993 The suborder Suiformes. In: Pigs, Peccaries and Hippos, edn 1, pp 1-4. Ed WLR Oliver. Gland, Switzerland: IUCN, The World Conservation Union.

Guimarães DA, Cardoso DL, Ferreira MAP \& Albuquerque NI 2013 Puberty in male collared peccary (Pecari tajacu) determined by quantitative analysis of spermatogenic cells. Acta Amazonica 43 1-8. (doi:10.1590/S0044-59672013000100001)

Honaramooz A, Snedaker A, Boiani M, Scholer H, Dobrinski I \& Schlatt S 2002 Sperm from neonatal mammalian testes grafted in mice. Nature 418 778-781. (doi:10.1038/nature00918)

Honaramooz A, Li MW, Penedo MC, Meyers S \& Dobrinski I 2004 Accelerated maturation of primate testis by xenografting into mice. Biology of Reproduction 70 1500-1503. (doi:10.1095/biolreprod.103.025536)

Honaramooz A, Megee SO, Rathi R \& Dobrinski I 2007 Building a testis: formation of functional testis tissue after transplantation of isolated porcine (Sus scrofa) testis cells. Biology of Reproduction 76 43-47. (doi:10.1095/biolreprod.106.054999)

Honaramooz A, Cui XS, Kim NH \& Dobrinski I 2008 Porcine embryos produced after intracytoplasmic sperm injection using xenogeneic pig sperm from neonatal testis tissue grafted in mice. Reproduction, Fertility, and Development 20 802-807. (doi:10.1071/RD08093)

Kita K, Watanabe T, Ohsaka K, Hayashi H, Kubota Y, Nagashima Y, Aoki I, Taniguchi H, Noce T, Inoue K et al. 2007 Production of functional spermatids from mouse germline stem cells in ectopically reconstituted seminiferous tubules. Biology of Reproduction 76 211-217. (doi:10. 1095/biolreprod.106.056895)

Nakai M, Kaneko H, Somfai T, Maedomari N, Ozawa M, Noguchi J, Ito J, Kashiwazaki N \& Kikuchi K 2010 Production of viable piglets for the first time using sperm derived from ectopic testicular xenografts. Reproduction 139 331-335. (doi:10.1530/REP-09-0509)

Oatley JM, de Avila DM, Reeves JJ \& McLean DJ 2004 Spermatogenesis and germ cell transgene expression in xenografted bovine testicular tissue. Biology of Reproduction 71 494-501. (doi:10.1095/biolreprod. 104.027953)

Park CH, Uh KJ, Mulligan BP, Jeung EB, Hyun SH, Shin T, Ka H \& Lee CK 2011 Analysis of imprinted gene expression in normal fertilized and uniparental preimplantation porcine embryos. PLoS ONE 6 e22216. (doi:10.1371/journal.pone.0022216)

Peres CA 1996 Population status of white-lipped Tayassu pecary and collared peccaries T. tajacu in hunted and unhunted Amazonian forests.
Biological Conservation 77 115-123. (doi:10.1016/0006-3207(96) 00010-9)

Pereyra-Bonnet F, Fernández-Martín R, Olivera R, Jarazo J, Vichera G, Gibbons A \& Salamone D 2008 A unique method to produce transgenic embryos in ovine, porcine, feline, bovine and equine species. Reproduction, Fertility, and Development 20 741-749. (doi:10.1071/RD07172)

Rathi R, Honaramooz A, Zeng W, Turner R \& Dobrinski I 2006 Germ cell development in equine testis tissue xenografted into mice. Reproduction 131 1091-1098. (doi:10.1530/rep.1.01101)

Robinson JG \& Redford KH 1991 The use and conservation of wildlife. In Neotropical Wildlife Use and Conservation, edn 1, pp 3-5. Eds JC Robinson \& KH Redford. Chicago, USA: The University of Chicago Press.

Rodriguez-Sosa JR \& Dobrinski I 2009 Recent developments in testis tissue xenografting. Reproduction 138 187-194. (doi:10.1530/REP-09-0012)

de Rooij DG \& Griswold MD 2012 Questions about spermatogonia posed and answered since 2000. Journal of Andrology 33 1085-1095. (doi:10.2164/jandrol.112.016832)

Ruddock NT, Wilson KJ, Cooney MA, Korfiatis NA, Tecirlioglu RT, French AJ, Schlatt S, Honaramooz A, Boiani M, Scholer HR et al. 2003 Progeny from sperm obtained after ectopic grafting of neonatal mouse testes. Biology of Reproduction 68 2331-2335. (doi:10.1095/ biolreprod.102.014894)

Schlatt S, Kim SS \& Gosden R 2002 Spermatogenesis and steroidogenesis in mouse, hamster and monkey testicular tissue after cryopreservation and heterotopic grafting to castrated hosts. Reproduction 124 339-346. (doi:10.1530/rep.0.1240339)

Schlatt S, Westernströer B, Gassei K \& Ehmcke J 2010 Donor-host involvement in immature rat testis xenografting into nude mouse hosts. Biology of Reproduction 82 888-895. (doi:10.1095/biolreprod.109.082073)

Snedaker AK, Honaramooz A \& Dobrinski I 2004 A game of cat and mouse: xenografting of testis tissue from domestic kittens results in complete cat spermatogenesis in a mouse host. Journal of Andrology 25 926-930. (doi:10.1002/j.1939-4640.2004.tb03163.x)

Received 11 November 2013

First decision 25 November 2013

Revised manuscript received 4 December 2013

Accepted 9 December 2013 